\title{
Dust and flour aeroallergen exposure in flour mills and bakeries
}

M J Nieuwenhuijsen, C P Sandiford, D Lowson, R D Tee, K M Venables, J C McDonald, A J Newman Taylor

\begin{abstract}
As part of an epidemiological study among workers exposed to flour total dust and flour aeroallergen concentrations were measured with personal samplers over a workshift in three large bakeries and four flour mills and packing stations. In the bakeries geometric means for total dust concentrations ranged from $0.4 \mathrm{mg} / \mathrm{m}^{3}$ in the bread wrapping area up to $6.4 \mathrm{mg} / \mathrm{m}^{3}$ at the dough brake. The flour aeroallergen concentrations ranged from $45.5 \mu \mathrm{g} / \mathrm{m}^{3}$ in the bread wrapping area up to $252.0 \mu \mathrm{g} / \mathrm{m}^{3}$ in the confectionary area. In the flour mills and packing stations the concentrations were higher with geometric means for total dust ranging from $0.5 \mathrm{mg} / \mathrm{m}^{3}$ in the office up to $16.9 \mathrm{mg} / \mathrm{m}^{3}$ for hygiene workers in an old mill. The flour aeroallergen concentrations ranged from $101.5 \mu \mathrm{g} / \mathrm{m}^{3}$ for transport workers up to $1728 \cdot 2 \mu \mathrm{g} / \mathrm{m}^{3}$ for hygiene workers. The relation between total dust and flour aeroallergen concentrations varied for different areas and depended on the use of products other than flour.
\end{abstract}

(Occup Environ Med 1994;51:584-588)

As part of a seven year prospective longitudinal epidemiological study to explore the relation between occupational exposure to flour and respiratory, eye, and skin symptoms, and skin sensitivity we measured personal exposure to total dust and flour aeroallergen in several British flour mills and bakeries. The first results have been reported in a companion paper. $^{1}$ This paper describes the intensity measurements used to provide exposure estimates for subjects in the epidemiological study, and the relation between total dust and flour aeroallergen concentrations.

Bakers' asthma was described in antiquity ${ }^{2}$ and remains among the commonest causes of occupational asthma in Britain today. ${ }^{3}$ Several studies have shown that flour inhaled at work can cause specific immunological changes, respiratory symptoms, and asthma, and that an increase in duration and intensity of exposure was associated with an increase in prevalence of symptoms and sensitisation..$^{4-7}$

Flour and its additives contain many antigens ${ }^{89}$ but as an assay to measure flour antigens has been developed only recently, ${ }^{1011}$ total dust concentration has been used as a surrogate. ${ }^{46}$ In a study of one bakery ${ }^{10}$ flour aeroallergen only showed a relation with total dust at concentrations above $5 \mathrm{mg} / \mathrm{m} .^{3}$ The few studies that have published concentrations of flour dust showed considerable differences in exposure levels between jobs and tasks in different areas of flour mills and bakeries. ${ }^{4} 6^{12-15}$

\section{Material and methods} EXPOSURE MEASUREMENTS

We surveyed three large modern British bakeries (between 200 and 450 employees each), three flour mills with flour packing stations (60-200 employees each), and a flour packing station (30 employees). All three generally operated for 24 hours a day in several shifts. An occupational hygienist (MJN) visited each site and divided the employees into exposure groups, 11 in each flour mill and packing station and 15 in each bakery, using the zoning strategy described by Corn and Esmen ${ }^{16}$ and the uniform task categories described by Esmen. ${ }^{17}$ A detailed description of the exposure groups has been given elsewhere. ${ }^{18}$ In both the bakeries and flour mills we created a miscellaneous group for employees who could not be assigned to one of the other exposure groups. In general, the work done was well defined by job title except in the confectionary area of the bakeries. These areas were divided into three, which we refer to as: the "dough brake", "confectionary/flour involved", and "confectionary/no flour". The second of these included the oven men and the third the finishing area behind the oven.

A random sample of workers of one shift of each exposure group, measured on different days with sufficient numbers to include at least one worker of the $10 \%$ highest exposed, were invited to wear a personal sampler (Casella AFC123, Casella London Ltd, Bedford) for a whole workshift. The personal samplers were connected to seven hole sampling heads (Casella London Ltd, Bedford) containing polytetrafluoroethylene (PTFE) filters $(1 \cdot 2 \mu \mathrm{m}$ pore size, $25 \mathrm{~mm}$ diameter; Sartorius Instruments Ltd, GB-Belmont, Surrey) at a flow rate of $2 \mathrm{l} / \mathrm{min}$. For total dust measurement the filters were weighed before and after sampling on a six figure balance (Sartorius R180D; Sartorius Instruments Ltd, GB-Belmont, Surrey) and returned to the laboratory for elution and flour aeroallergen quantification. The limit of detection for dust was $0.12 \mathrm{mg}$ and for flour aeroallergen $1 \mu \mathrm{g} / \mathrm{ml}$. The coefficient of variation, measured with stationary samples, was $15 \cdot 5 \%$ for 
Table 1 Total dust and flour aeroallergen measurements in the bakeries obtained by personal sampling

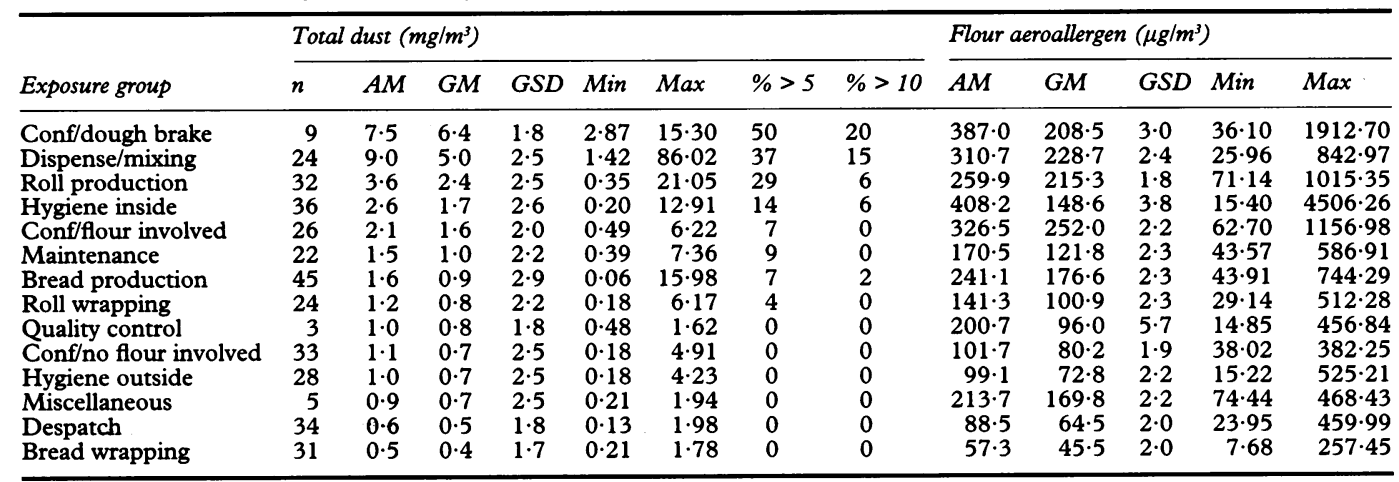

$\mathrm{n}=$ Number of samples; $\mathrm{AM}=$ arithmetic mean; $\mathrm{GM}=$ geometric mean; $\mathrm{GSD}=$ geometric standard deviation; Min = minimum value measured; Max = maximum value measured; $\%>5=$ percentage of total dust measurements exceeding $5 \mathrm{mg} / \mathrm{m}^{3} ; \%>10=$ percentage of total dust measurements exceeding $10 \mathrm{mg} / \mathrm{m}^{3}$; Conf = confectionary area.

dust and $36.5 \%$ for flour aeroallergen. Samples under the detection limit were assigned a value half this limit. Average total dust and flour aeroallergen concentrations were calculated for each group and then assigned to each worker in the group.

\section{ELUTION AND ASSAY}

Female half-lop rabbits were immunised with a mixture of wholemeal and hard white wheat bread flours (Telford's Bakery Maidstone, Kent UK). When an IgG antibody titre of 1:1024 was reached the rabbit antisera were purified by caprylic acid and ammonium sulphate precipitation, followed by dialysis, freeze drying, and storage at $-20^{\circ} \mathrm{C}$. Canadian Western Red Spring (CWRS) wholemeal flour was obtained additive free from the Flour Milling and Baking Research Association (Chorleywood UK). After overnight extraction in $0.1 \mathrm{M}$ ammonium hydrogen carbonate $\mathrm{pH} 7 \cdot 65$, the flour solution was centrifuged, dialysed, and freeze dried and stored at $-20^{\circ} \mathrm{C}$. The material sampled in the bakeries and mills was eluted from the PTFE

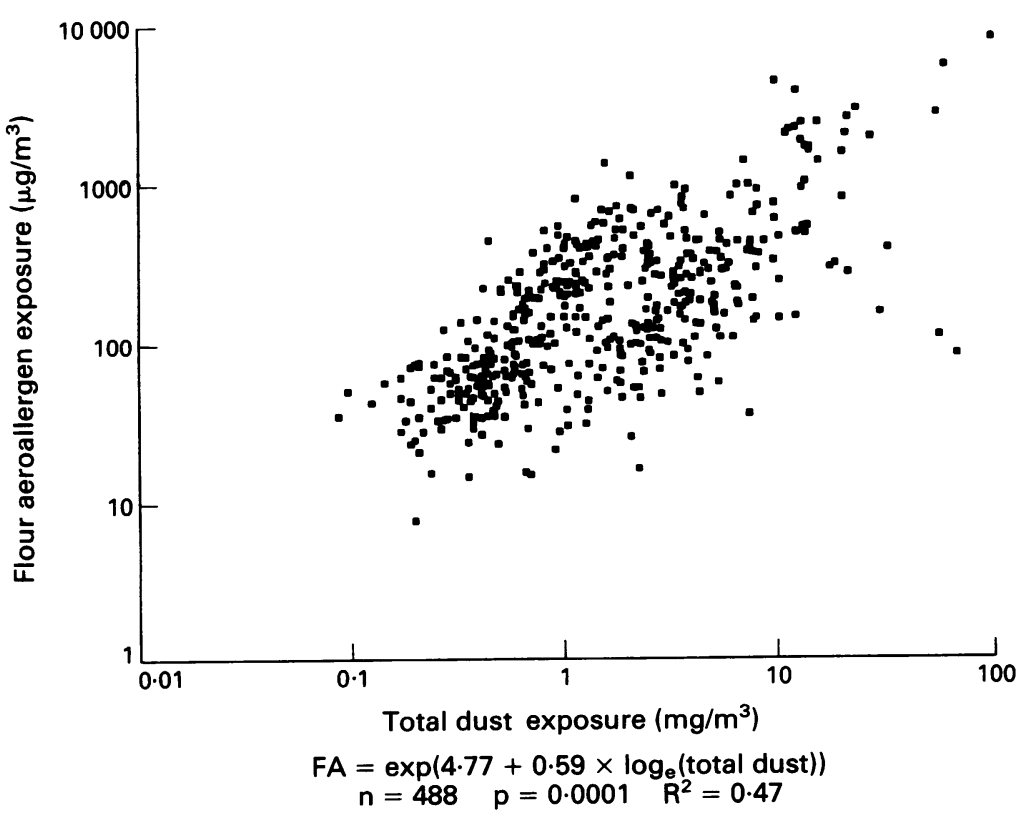

Figure 1 Plot of the flour aeroallergen measurements $\left(\mu \mathrm{g} / \mathrm{m}^{3}\right)$ against the total dust measurements $\left(\mathrm{mg} / \mathrm{m}^{3}\right) . n=$ number of samples; $p=$ significance level; $R^{2}=R^{2}$ of the model; $F A=$ flour aeroallergen. filters with $0.5 \% \mathrm{v} / \mathrm{v}$ Tween $20(2 \mathrm{ml}$ in $0.1 \mathrm{M}$ ammonium hydrogen carbonate $\mathrm{pH} 7 \cdot 65$ ). Flour contains several allergenic proteins. ${ }^{19}$ The allergen content was measured by an inhibition assay ${ }^{11}$ with CWRS wholemeal flour extract coated to plates $(100 \mu \mathrm{l})$, a CWRS wholemeal flour standard curve (11 dilutions) or filter extract $(100 \mu \mathrm{l})$, and purified rabbit IgG antibody $(100 \mu \mathrm{l})$. Detection of antibody binding was accomplished with ${ }^{125}$ I Protein-A (Amersham UK). The assay had upper and lower detection limits of 200 and $1 \mu \mathrm{g} / \mathrm{ml}$ respectively. The standard curves were generated with a $\gamma$ counter (Cobra 5005 Packard) four parameter logistic fitting software. The flour aeroallergen concentration was calculated from the standard curve and corrected for the volume of air sampled and the reconstitution volume of the eluted filter.

\section{STATISTICAL ANALYSIS}

The degree of variation attributable to exposure grouping and to the different sites in the population was assessed by analysis of variance (SAS, SAS Institute Inc, Cary NC, USA). The log transformed shift measurements were used as the dependent variable in a multivariate model and the sites and exposure groups as independent variables. An interaction term was added when appropriate. Analysis of covariance was used to compare slopes of the relation between flour aeroallergen and total dust exposure in different areas.

\section{Results}

TOTAL DUST CONCENTRATIONS

In all, 522 shift samples were collected of which 27 were discarded because of irregularities of the filter or breakdown of the sampler. Total dust measurements followed an approximately log normal distribution with $83.3 \%$ of the samples below $5 \mathrm{mg} / \mathrm{m}^{3}$ and $6.5 \%$ above $10 \mathrm{mg} / \mathrm{m}^{3}$.

In the bakeries there were no significant differences in total dust concentrations between sites $(F=1 \cdot 10, \mathrm{p}=0 \cdot 34)$ and $43 \%$ of the variation was explained by differences between exposure groups $(F=18.33$, $\mathrm{p}=0.0001)$. The highest concentrations in the bakeries were in dispensing and mixing areas and dough brakes in the confectionary 
Figure 2 Plot of the flour aeroallergen measurements $\left(\mu \mathrm{mg} / \mathrm{m}^{3}\right)$ against the total dust measurements in different areas of the bakeries, flour mills, and packing stations. $n=$ number of samples; $p=$ significance value; $R^{2}=R^{2}$ of the model; $F A=$ flour aeroallergen.

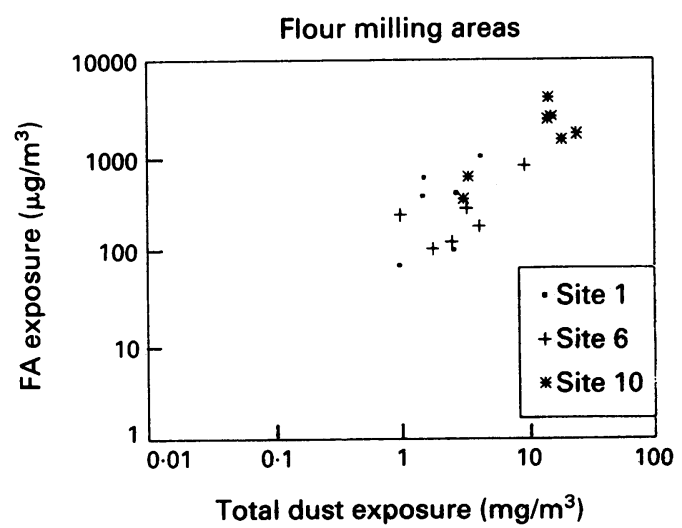

$F A=\exp \left(4.79+0.96 \times \log _{e}\right.$ (total dust) $n=19 \quad p=0.0001 \quad R^{2}=0.65$
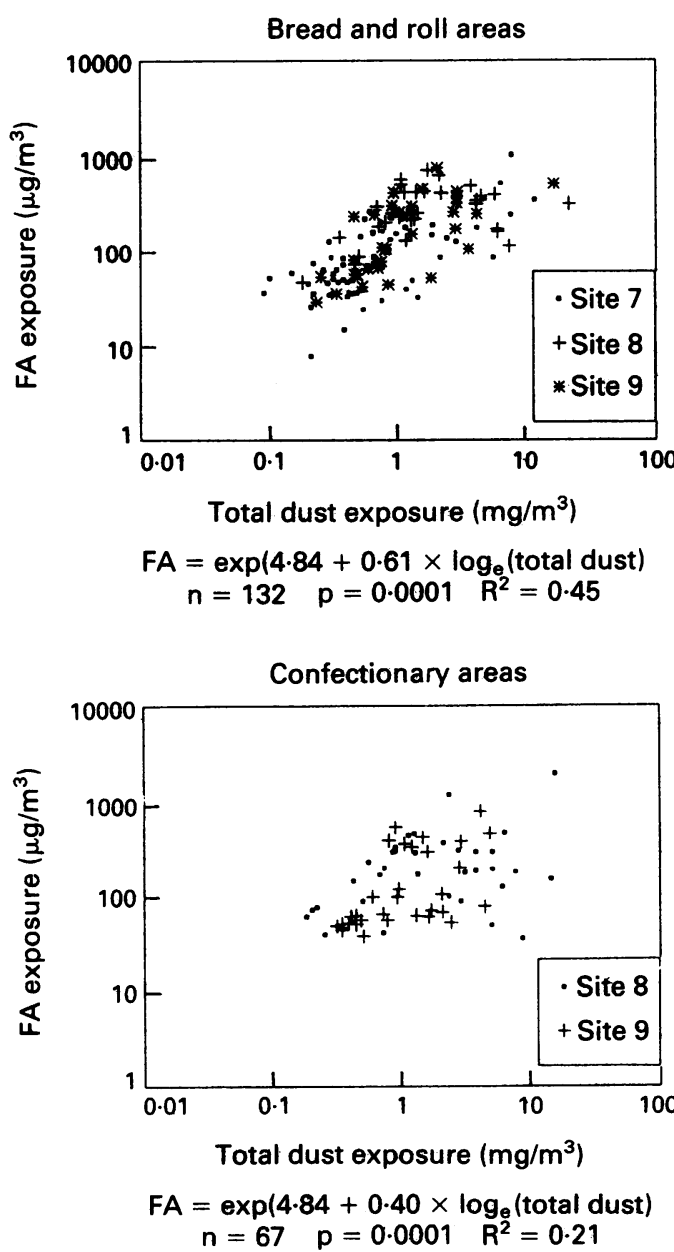

areas and the lowest in the bread wrapping and despatch areas (table 1).

In the flour mills and packing stations differences between exposure groups also explained much of the variation $(31 \%)$ $(F=11.07, \mathrm{p}=0.0001)$. The differences between the sites $(F=2 \cdot 82, \mathrm{p}=0: 04)$ and the interaction of exposure groups and sites $(F=2 \cdot 10, \mathrm{p}=0.03)$ were significant but small ( $4 \%$ and $15 \%$ respectively). Differences between the flour mills were mainly explained by an older site (site 10) where the exposure levels were much higher. An analysis of variance excluding site 10 showed no significant difference $(F=1.80, \mathrm{p}=0.17)$ between the sites but still a significant difference between

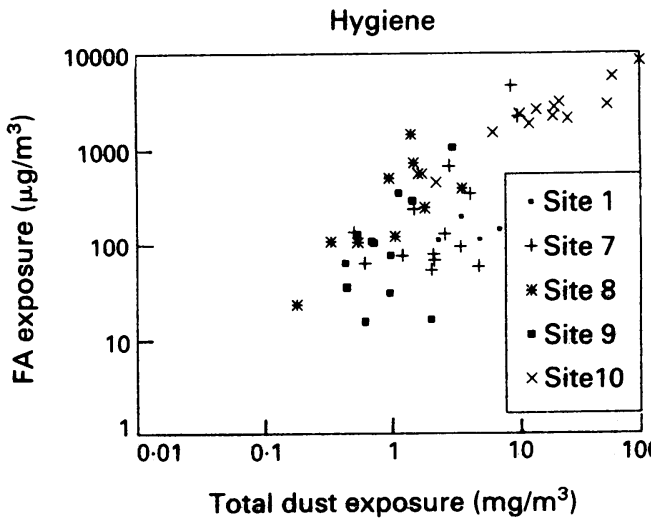

$F A=\exp \left(4.61+0.88 \times \log _{e}\right.$ (total dust) $n=53 \quad p=0.0001 \quad R^{2}=0.61$

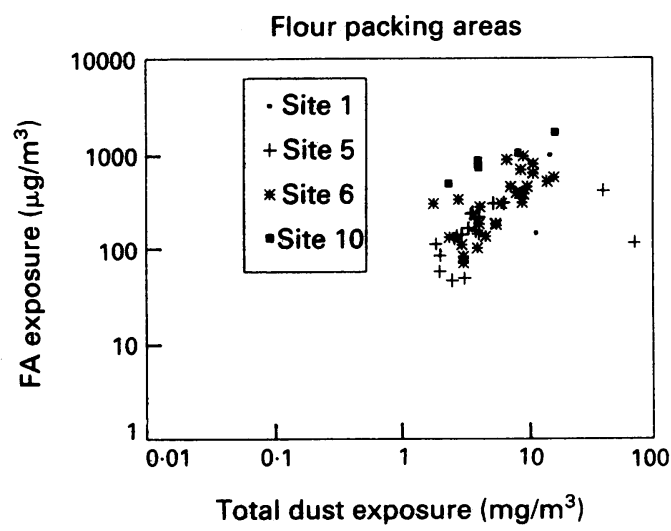

$F A=\exp \left(4.52+0.59 \times \log _{e}\right.$ (total dust) $n=53 \quad p=0.0001 \quad R^{2}=0.27$

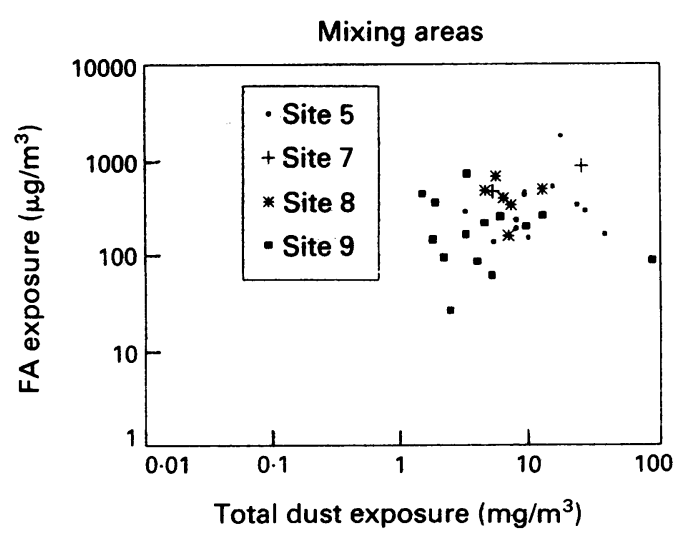

$F A=\exp \left(5.23+0.16 \times \log _{e}\right.$ (total dust) $n=34 \quad p=0.31 \quad R^{2}=0.03$

exposure groups $(F=7.52, \mathrm{p}=0.0001)$, which explained $46 \%$ of the variation in total dust exposure. Therefore table 2 gives the characteristics of the total dust measurements in the flour mill by exposure groups, combined for sites 1, 5, and 6 and separately for site 10 . Overall the total dust concentrations were higher in the flour mills and packing stations than in the bakeries, with the highest values recorded in the packing and the mixing areas and, in particular at site 10, among flour millers and the hygiene workers (cleaners).

FLOUR AEROALLERGEN CONCENTRATIONS Of the 495 dust samples 488 were analysed for flour aeroallergen. The flour aeroallergen 
Table 2 Total dust and flour aeroallergen measurements in the flour mills and packing stations obtained by personal sampling

\begin{tabular}{|c|c|c|c|c|c|c|c|c|c|c|c|c|c|}
\hline \multirow[b]{2}{*}{ Exposure group } & \multicolumn{8}{|c|}{ Total dust ( $\left.\mathrm{mg} / \mathrm{m}^{3}\right)$} & \multicolumn{5}{|c|}{ Flour aeroallergen $\left(\mu \mathrm{g} / \mathrm{m}^{3}\right)$} \\
\hline & $n$ & $A M$ & $G M$ & $G S D$ & Min & $\operatorname{Max}$ & $\%>5$ & $\%>10$ & $A M$ & $G M$ & $G S D$ & Min & $\operatorname{Max}$ \\
\hline \multicolumn{14}{|l|}{ Sites 1,5 , and 6: } \\
\hline Mixing area & 12 & $13 \cdot 8$ & $11 \cdot 0$ & $2 \cdot 0$ & 3.04 & $36 \cdot 68$ & 79 & 36 & $406 \cdot 8$ & $303 \cdot 9$ & $2 \cdot 0$ & $135 \cdot 27$ & $1737 \cdot 64$ \\
\hline Packing area & 48 & $8 \cdot 3$ & $5 \cdot 7$ & $2 \cdot 2$ & 1.84 & $70 \cdot 95$ & 41 & 18 & $304 \cdot 7$ & $227 \cdot 6$ & $\mathbf{2} \cdot \mathbf{2}$ & 45.53 & 970.69 \\
\hline Hygi & 4 & $5 \cdot 6$ & $5 \cdot 2$ & $1 \cdot 6$ & $2 \cdot 85$ & 8.98 & 50 & 0 & $137 \cdot 9$ & $134 \cdot 3$ & $1 \cdot 3$ & $109 \cdot 16$ & $190 \cdot 35$ \\
\hline Warehouse & 5 & 3.9 & 3.4 & 1.8 & 1.47 & $6 \cdot 29$ & 40 & 0 & $334 \cdot 5$ & $277 \cdot 1$ & $2 \cdot 0$ & $108 \cdot 57$ & $718 \cdot 10$ \\
\hline Flour mill & 12 & 3.0 & $2 \cdot 4$ & 1.9 & 0.96 & $9 \cdot 40$ & 8 & 0 & 341.3 & $248 \cdot 3$ & $2 \cdot 3$ & 68.94 & 950.06 \\
\hline Quality control & 6 & $2 \cdot 1$ & 1.9 & 1.6 & 1.26 & 4.55 & 0 & 0 & $285 \cdot 7$ & $182 \cdot 0$ & $2 \cdot 9$ & 43.66 & $832 \cdot 86$ \\
\hline Maintenance & 7 & $3 \cdot 7$ & $1 \cdot 8$ & $3 \cdot 1$ & 0.76 & $15 \cdot 98$ & 14 & 14 & $320 \cdot 4$ & $186 \cdot 7$ & $3 \cdot 3$ & $27 \cdot 74$ & $1064 \cdot 42$ \\
\hline Transport & 5 & $2 \cdot 8$ & $1 \cdot 7$ & $3 \cdot 1$ & 0.47 & $7 \cdot 40$ & 14 & 0 & $105 \cdot 0$ & 101.5 & $1 \cdot 4$ & $65 \cdot 14$ & 128.91 \\
\hline Miscellaneous & 6 & 1.5 & $1 \cdot 3$ & 1.6 & 0.67 & $2 \cdot 92$ & 0 & 0 & $158 \cdot 2$ & $147 \cdot 5$ & $1 \cdot 5$ & $91 \cdot 13$ & 249.91 \\
\hline Wheat mill & 4 & $2 \cdot 0$ & $1 \cdot 2$ & $3 \cdot 0$ & 0.48 & $5 \cdot 83$ & 25 & 0 & 16 & $154 \cdot 0$ & 1.6 & $77 \cdot 59$ & 236.95 \\
\hline Office & 2 & 0.6 & 0.5 & $2 \cdot 2$ & 0.28 & 0.84 & 0 & 0 & $129 \cdot 3$ & $109 \cdot 8$ & $2 \cdot 3$ & $61 \cdot 08$ & $197 \cdot 43$ \\
\hline \multicolumn{14}{|l|}{ Site 10: } \\
\hline Hygiene & 14 & $32 \cdot 1$ & $16 \cdot 9$ & $3 \cdot 7$ & 1.96 & $127 \cdot 80$ & 79 & 71 & $2552 \cdot 1$ & $1728 \cdot 2$ & $2 \cdot 9$ & $116 \cdot 42$ & $8321 \cdot 00$ \\
\hline Flour mill & 7 & $13 \cdot 4$ & $10 \cdot 6$ & $2 \cdot 3$ & $3 \cdot 10$ & $24 \cdot 23$ & 71 & 71 & $1805 \cdot 7$ & 1388.5 & $2 \cdot 4$ & $337 \cdot 26$ & $3908 \cdot 11$ \\
\hline Packing area & 5 & $7 \cdot 2$ & $5 \cdot 7$ & $2 \cdot 1$ & 2.41 & 16.75 & 40 & 20 & $822 \cdot 7$ & $573 \cdot 2$ & $3 \cdot 1$ & $87 \cdot 34$ & $1660 \cdot 75$ \\
\hline Quality control & 4 & $3 \cdot \overline{0}$ & $2 \cdot 8$ & $1 \cdot 5$ & $1 \cdot 81$ & $4 \cdot 61$ & 0 & 0 & $251 \cdot 6$ & $228 \cdot 4$ & $1 \cdot 7$ & 110.01 & 357.62 \\
\hline Wheat mill & 2 & $2 \cdot 0$ & 1.9 & $1 \cdot 3$ & 1.57 & $2 \cdot 39$ & 0 & 0 & $417 \cdot 3$ & $299 \cdot 0$ & $3 \cdot 4$ & $126 \cdot 16$ & $708 \cdot 40$ \\
\hline
\end{tabular}

$\mathrm{n}=$ Number of samples; $\mathrm{AM}=$ arithmetic mean; $\mathrm{GM}=$ geometric mean; $\mathrm{GSD}=$ geometric standard deviation; $\mathrm{Min}=$ minimum value measured; $\operatorname{Max}=$ maximum value measured; $\%>5=$ percentage of total dust measurements exceeding $5 \mathrm{mg} / \mathrm{m}^{3} ; \%>10=$ percentage of total dust measurements exceeding $10 \mathrm{mg} / \mathrm{m}^{3}$.

measurements followed an approximately log normal distribution. In the bakeries there was a significant difference between the sites $(F=3 \cdot 89, \mathrm{p}=0.02)$ but this explained only $2 \%$ of the variation in the flour aeroallergen concentrations; exposure groups explained a much larger proportion (23\%) $(F=9.35$, $\mathrm{p}=0.0001)$. In general the highest and lowest mean concentrations were found in the same areas as those for total dust exposure, but with a smaller range (table 1).

In the flour mills and packing stations the pattern was different. Differences between exposure groups explained only $7 \%$ of the variation in flour aeroallergen exposure $(F=7.58, \mathrm{p}=0.02)$ whereas differences between sites explained $47 \% \quad(F=27.92$, $\mathrm{p}=0.0001)$. Exclusion of site 10 reduced the first to $0 \%(F=2.09, \mathrm{p}=0.03)$ and the second to $1 \%(F=5.74, \mathrm{p}=0.004)$. Table 2 gives the characteristics of the flour aeroallergen exposure in the flour mills and packing stations by exposure groups combined for sites 1, 5, and 6 and separately for site 10 . The differences in mean flour aeroallergen exposure between the exposure groups were much smaller than for mean total dust expo-

Figure 3 Plot of the geometric means $(G M s)$ of
flour aeroallergen $\left(\mu g / m^{3}\right)$ against GMs of total dust $\left(\mu g / m^{3}\right)$.

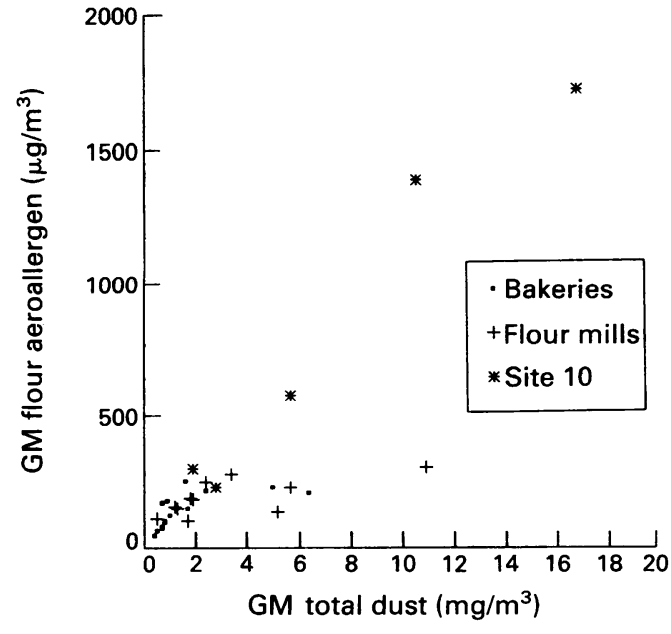

sure and site 10 had much higher flour aeroallergen exposure than the other sites.

\section{RELATION OF TOTAL DUST AND FLOUR} AEROALLERGEN CONCENTRATIONS

The log transformed flour aeroallergen and total dust measurements had a linear relation with a slope of $0.59(\mathrm{SE}=0.03, \mathrm{p}=0.0001)$ (fig 1). This relation was also examined in different production areas (fig 2). The relation disappeared in the mixing areas, was weak although significant in the confectionary areas, and stronger in the flour milling areas and for hygiene workers. The slopes were not significantly different. A plot of geometric means of flour aeroallergen against geometric means of total dust for the various exposure groups showed an almost linear relation, with some exceptions (fig 3). For example, in the mixing areas the dust concentrations were high but the flour aeroallergen concentrations were relatively low.

\section{Discussion}

This was the first large environmental assessment to measure personal total dust and flour aeroallergen levels at different bakeries and flour mills. Total dust concentrations were similar to those in previous studies. ${ }^{414}$ Exposure in the flour mills and packing stations was in general higher than in the bakeries. The highest dust exposure in the flour mills and packing stations occurred in the mixing and flour packing areas, except at site 10 where poorly maintained equipment caused high total dust exposure in all areas. The highest dust exposure in the bakeries occurred in the dough brakes and the mixing areas. Low dust exposures - for example, in the despatch and bread wrapping areas-were more common in the bakeries than in the flour mills. The use of exposure groups proved useful in identifying patterns of total dust exposure. There was no difference in total dust concentrations between sites for the bakeries. Three out of four flour mills and 
packing stations had similar exposures; the exception was an old mill.

The flour aeroallergen concentrations followed a similar pattern to the total dust concentrations. In the bakeries the differences in flour aeroallergen concentrations between sites were small but considerable between exposure groups. In the flour mills and packing stations little or no differences between exposure groups or sites were found except for one old site where flour aeroallergen concentrations where considerably higher. The geometric SDs for both dust and flour aeroallergen varied between 2 or 3 suggesting fairly large variability but this is not uncommon for hygiene data. ${ }^{20}$

The relation between total dust and flour aeroallergen concentrations was dependent on production area, with strong linear relations in the flour milling areas but none in the mixing areas. The second was probably due to a large amount of non-flour products such as salt and fat being used, which also may explain the weak relation in the confectionary areas. The relation between geometric means of dust and of flour aeroallergen for the various exposure groups was linear with a few exceptions, such as the mixing areas.

Bakers' asthma and related diseases are manifestations of an allergic reaction to inhaled flour aeroallergens. Most studies have used dust measurements as a surrogate for flour aeroallergen. Our results suggest that such approximations could be used in many departments but might lead to an over-estimation of the flour aeroallergen exposure in others.

In this study a considerable proportion of the variation for both total dust and flour aeroallergen concentrations could not be explained by differences between exposure groups or sites; this residual variance, which includes within and between worker variation, needs further investigation. The exposure measurements covered a whole work shift. Other studies have shown that short term high exposures occur, which might be important for the development of diseases. ${ }^{1115}$ This aspect needs further investigation.

We acknowledge the help of Mr L van Amelsvoort with environmental sampling, Miss J Welch with air filter elution, Mr F Gill and Mrs D Glass for advice on exposure assessment, and the management and workers for their cooperation.
The work was supported by grants from the Health and Safety Executive, National Asthma Campaign, Department of Health and Social Security, and the Royal Society.

1 Cullinan P, Lowson D, Nieuwenhuijsen MJ, Sandiford C, Tee RD, Venables KM, et al. Work related symptoms, sensitisation, and estimated exposure in workers not previously exposed to flour. Occup Environ Med 1994; 51:579-83.

2 Rammazzine B. De Morbis Artificum. Latin text 1713. Translation in: Wright WC. Diseases of workers. Chicago: University of Chicago, 1940 .

3 Meredith SK, Taylor VM, McDonald JC. Occupational respiratory disease in the United Kingdom: a report to the British Thoracic Society of Occupational Medicine by the SWORD project group. Br f Ind Med 1991; 48:292-8.

4 Musk AW, Venables KM, Crook B, et al. Respiratory symptoms, lung function and sensitisation to flour in symptoms, lung function and sensitisation to

5 Järvinen KAJ, Pirila V, Björksten F, Keskinen H, Lehtinen M, Stubb S. Unsuitability of bakery work for a person with atopy. A study of 234 bakery workers. Ann Allergy 1979;42:192-5.

6 Hartmann AL. Berufsallergien bei bäckern. Epidemiologie, diagnose, therapie und phrophylaxe versicherungsrecht. München-Deisenhofen: Dustri-Verlag Dr Karl Feistle, 1986.

7 Herxheimer $H$. The skin sensitivity to flour of bakers' apprentices. Acta Allergologica 1973;28:42-9.

8 Pfeil T, Schwabl U, Ulmer WT, König W. Western blot analysis of water-soluble wheat flour (Triticum vulgaris)
allergens. Int Arch Allergy Appl Immunol 1990;91: 224-31.

9 Brisman J, Belin L. Clinical and immunological responses to occupational exposure to $a$-amylase in the baking industry. Br F Ind Med 1991;48:604-8.

10 Tee RD, Gordon DJ, Gordon S, et al. Immune response to flour and dust mites in a United Kingdom bakery. $\mathrm{Br} F$ Ind Med 1992;49:581-7.

11 Sandiford CP, Tee RD, Newman Taylor AJ. A rabbit antibody assay to measure wheat flour aeroallergen [abstract]. Allergy 1992;47(suppl 1):55.

12 Masalin KE, Degerth RK, Murtomaa HT. Airborne sugar and flour dust in the Finnish confectionary industry. Applied Industrial Hygiene 1988;3:231-5.

13 Awad el Karim MA, Gad el Rab MO, Omer AA, El Haimi YAA. Respiratory and allergic disorders in workers exposed to grain and flour dust. Arch Environ Health exposed to grain

14 Houba R, Zweers T. Longfunktieonderzoek in een meelfabriek. Verslag no 313. Wageningen: Vakgroep Gezondheidsleer en Luchthygiene en -verontreiniging. Landbouwuniversiteit, 1988. (In Dutch.)

15 Gimenez C. Etude des manifestations réspiratoires chez des ouvriers de meunerie. Thèse pour le Doctorat en Médecine. Paris: Faculté de Médecine Paris 6, Université Pierre et Marie Curie, 1991. (In French.)

16 Corn M, Esmen NA. Workplace exposure zones for classification of employee exposures to physical and chemical agents. Am Ind Hyg Assoc $\mathcal{\exists} 1979 ; 40: 47-57$.

17 Esmen N. On the estimation of occupational health risks. In: Esmen NA and Mehlman MA, eds. Occupational and In: Esmen NA and Mehlman MA, eds. Occupational and
industrial concepts and methods. Princeton New Jersey: industrial concepts and methods. Princeton New
Princeton Scientific Publishers Inc. 1984, 45-75.

18 Nieuwenhuijsen MJ. Exposure to aeroallergens: determinants, exposure levels, and skin prick test reactions in bakeries, flour mills and research institutes [PhD thesis]. London University of London, 1993.

19 Sandiford CP, Tee RD, Newman Taylor AJ. Identification of major allergenic flour proteins in order to develop assays to measure flour aeroallergen. Clin Exp Allergy 1992;20(suppl):3.

20 Kromhout H, Symanski E, Rappaport SM. A comprehensive evaluation of within and between worker components of occupational exposure to chemical agents. Ann Occup Hyg 1993;37:253-70. 